\title{
Occurrence of lower cloud albedo in ship tracks
}

\author{
Y.-C. Chen ${ }^{1}$, M. W. Christensen ${ }^{2}$, L. Xue ${ }^{3}$, A. Sorooshian ${ }^{4}$, G. L. Stephens ${ }^{5}$, R. M. Rasmussen ${ }^{3}$, and J. H. Seinfeld ${ }^{1,6}$ \\ ${ }^{1}$ Division of Engineering and Applied Science, California Institute of Technology, Pasadena, California, USA \\ ${ }^{2}$ Department of Atmospheric Science, Colorado State University, Fort Collins, Colorado, USA \\ ${ }^{3}$ National Center for Atmospheric Research (NCAR), Boulder, Colorado, USA \\ ${ }^{4}$ Department of Chemical and Environmental Engineering/Atmospheric Sciences, The University of Arizona, Arizona, USA \\ ${ }^{5}$ Jet Propulsion Laboratory, California Institute of Technology, Pasadena, California, USA \\ ${ }^{6}$ Division of Chemistry and Chemical Engineering, California Institute of Technology, Pasadena, California, USA
}

Correspondence to: J. H. Seinfeld (seinfeld@caltech.edu)

Received: 9 May 2012 - Published in Atmos. Chem. Phys. Discuss.: 31 May 2012

Revised: 28 August 2012 - Accepted: 29 August 2012 - Published: 12 September 2012

\begin{abstract}
The concept of geoengineering by marine cloud brightening is based on seeding marine stratocumulus clouds with sub-micrometer sea-salt particles to enhance the cloud droplet number concentration and cloud albedo, thereby producing a climate cooling effect. The efficacy of this as a strategy for global cooling rests on the extent to which aerosolperturbed marine clouds will respond with increased albedo. Ship tracks, quasi-linear cloud features prevalent in oceanic regions impacted by ship exhaust, are a well-known manifestation of the effect of aerosol injection on marine clouds. We present here an analysis of the albedo responses in ship tracks, based on in situ aircraft measurements and three years of satellite observations of 589 individual ship tracks. It is found that the sign (increase or decrease) and magnitude of the albedo response in ship tracks depends on the mesoscale cloud structure, the free tropospheric humidity, and cloud top height. In a closed cell structure (cloud cells ringed by a perimeter of clear air), nearly $30 \%$ of ship tracks exhibited a decreased albedo. Detailed cloud responses must be accounted for in global studies of the potential efficacy of sea-spray geoengineering as a means to counteract global warming.
\end{abstract}

\section{Introduction}

Marine stratocumulus clouds (MSc), covering, on average, nearly one-third of the ocean surface (Warren et al., 1988), exert a cooling influence on climate. It has been estimated that a $6 \%$ increase of the albedo of MSc would offset the warming by atmospheric $\mathrm{CO}_{2}$ doubling (Latham et al.,
2008). Based on the assumption that increasing aerosol number concentration leads to higher cloud droplet number concentration and an increase in cloud albedo (Twomey, 1991) (assuming constant liquid water path - LWP), a marine geoengineering scheme was proposed (Salter et al., 2008): using wind-driven spray-vessels that pump sub-micrometer seasalt particles into the air beneath MSc. The effect of injecting aerosols into the marine boundary layer has been evaluated in several global climate modeling studies with prescribed enhanced cloud droplet number concentration (Jones et al., 2009; Rasch et al., 2009; Bala et al., 2011), global aerosol microphysics models (Korhonen et al., 2010; Partanen et al., 2012; Pringle et al., 2012), parcel models (Russell et al., 1999; Bower et al., 2006), and cloud-system resolving models (Wang et al., 2011).

According to IPCC (2007), the median value of predicted global aerosol indirect radiative forcing is $-0.7 \mathrm{~W} \mathrm{~m}^{-2}$, with an uncertainty range from -1.8 to $-0.3 \mathrm{Wm}^{-2}$. Modeling the global aerosol indirect effect is challenging, as the representations of aerosol-cloud interactions in climate models are necessarily crude (Lohmann and Feichter, 2005). The sensitivity of clouds and precipitation to aerosol perturbations must account for buffering mechanisms (Stevens and Feingold, 2009). As both aerosol levels and meteorology (i.e., large-scale dynamic and thermodynamic state) govern the state of cloudiness, the coupling of these two factors complicates the interpretation of aerosol-cloud responses (Stevens and Brenguier, 2009).

Ship tracks serve as a well-known manifestation of marine aerosol-cloud interactions. There have been a number of observational studies of ship tracks, including in-situ airborne 
Table 1. Instrumentation Payload on CIRPAS Twin Otter.

\begin{tabular}{lll}
\hline Parameter & Instrument & Detected Size \\
\hline Particle Number Concentration & Condensation Particle Counter: CPC3010 & $\begin{array}{c}D_{\mathrm{p}}^{\mathrm{a}}>10 \mathrm{~nm} \\
D_{\mathrm{p}}>3 \mathrm{~nm}\end{array}$ \\
\hline Aerosol Size Distribution & \multicolumn{1}{c}{ CPC3025 } & $0.1-2.6 \mu \mathrm{m}$ \\
& Passive Cavity Aerosol Spectrometer Probe (PCASP) & $15 \mathrm{~nm}-1 \mu \mathrm{m}$ \\
\hline Cloud and Drizzle Drop Size Distribution & Scanning Differential Mobility Analyzer (DMA) & $0.4 \mu \mathrm{m}-1.6 \mathrm{~mm}$ \\
& Cloud, Aerosol, and Precipitation Spectrometer (CAPS) & $4-200 \mu \mathrm{m}$ \\
& Phase Doppler Interferometer (PDI) & $1-46 \mu \mathrm{m}$ \\
\hline Aerosol Bulk Composition & Forward Scattering Spectrometer Probe (FSSP) & $\sim 5-50 \mu \mathrm{m}$ \\
\hline Particle Properties & Gerber Light Diffraction (PVM-100 probe) & $D_{\mathrm{va}}^{\mathrm{c}} \sim 40 \mathrm{~nm}-1 \mathrm{~mm}$ \\
& Aerodyne Time-of-Flight Aerosol Mass Spectrometer (AMS) & \\
\hline Cloud Structures & Single-Particle Soot Photometer (SP2) & \\
\hline Particle and Droplet Inlets & Cloud Condensation Nuclei Counter (CCN Spectrometer) & \\
\hline Meteorological variables & Particle Soot Absorption Photometer (PSAP) & \\
(Temperature, relative humidity, wind properties, etc.) & Photoacoustic Soot Spectrometer (PASS-3) & \\
\hline
\end{tabular}

a Particle diameter.

b Drizzle drop size distribution is measured by the Cloud Imaging Spectrometer (CIP-2D), included in the CAPS package.

c Vacuum aerodynamic diameter.

measurements (e.g., Radke et al., 1989; Ferek et al., 1998; Durkee et al., 2000; Twohy et al., 2005; Lu et al., 2007, 2009) and remote sensing satellite observations (e.g., Coakley and Walsh, 2002; Schreier et al., 2007; Segrin et al., 2007; Lebsock et al., 2008; Christensen and Stephens, 2011, 2012). Whereas ample evidence exists that increased aerosol levels lead to more numerous and smaller cloud droplets, the response of cloud macrophysics (i.e., cloud thickness, LWP) to aerosol perturbations is not as clear-cut. Cloud macrophysical responses to increased aerosol levels can lead to either enhancement or diminution of cloud brightening. By utilizing both in situ aircraft measurements and A-Train satellite data, we present here an analysis of the factors that control the sign and magnitude of the aerosol indirect effect in ship tracks.

\section{Data description}

\subsection{In-situ E-PEACE data}

The Eastern Pacific Emitted Aerosol Cloud Experiment (EPEACE) aircraft campaign, carried out in July and August 2011 (30 research flights) over the eastern Pacific adjacent to the coast of Monterey, California, was designed to provide a well-defined data set on MSc responses to ship emissions (Russell et al., 2012). This area of widespread ship traffic is characterized by layers of persistent stratocumulus clouds. The Center for Interdisciplinary Remotely-Piloted Aircraft
Studies (CIRPAS) Twin Otter aircraft was employed, with a full payload of state-of-the-art aerosol and cloud instrumentation (Table 1). In the E-PEACE campaign, three types of particle sources were used as cloud perturbations: (a) combustion exhaust from large container/tanker vessels (dry diameters 50-100 nm); (b) organic smoke generated onboard the Research Vessel Point Sur (dry diameters $100 \mathrm{~nm}-1 \mu \mathrm{m}$ ); and (c) aircraft-emitted milled salt particles (dry diameters 3-5 $\mu \mathrm{m}$ ). The present work focuses on the effect of combustion exhaust from large container/tanker ships. Over the 30 flights carried out, approximately 45 cargo/tanker ship emissions and their effect on cloud microphysical and macrophysical properties were probed. Several flight strategies were applied. In most flights, the aircraft executed a zigzag pattern in and out of the plume, with below cloud, in-cloud (cloud base, mid-cloud, cloud top), and above cloud legs. In four of the flights, spiral soundings and/or slanted ascents (Fig. 1) were conducted in areas clearly influenced by the ship exhaust and in adjacent areas relatively free of ship exhaust, from which the cloud base/top heights, LWP, and cloud albedo, using the vertical boundary layer profile, were obtained. This strategy of spiral sounding and slanted ascents proved ideal to probe the response of cloud properties with respect to ship-emitted particles: ship exhaust and background marine aerosol below cloud, in cloud, and above cloud were probed, with the perturbed clouds subject to the same background meteorological conditions as those outside the region of exhaust impact. We focus here on these four research flights during E-PEACE. 

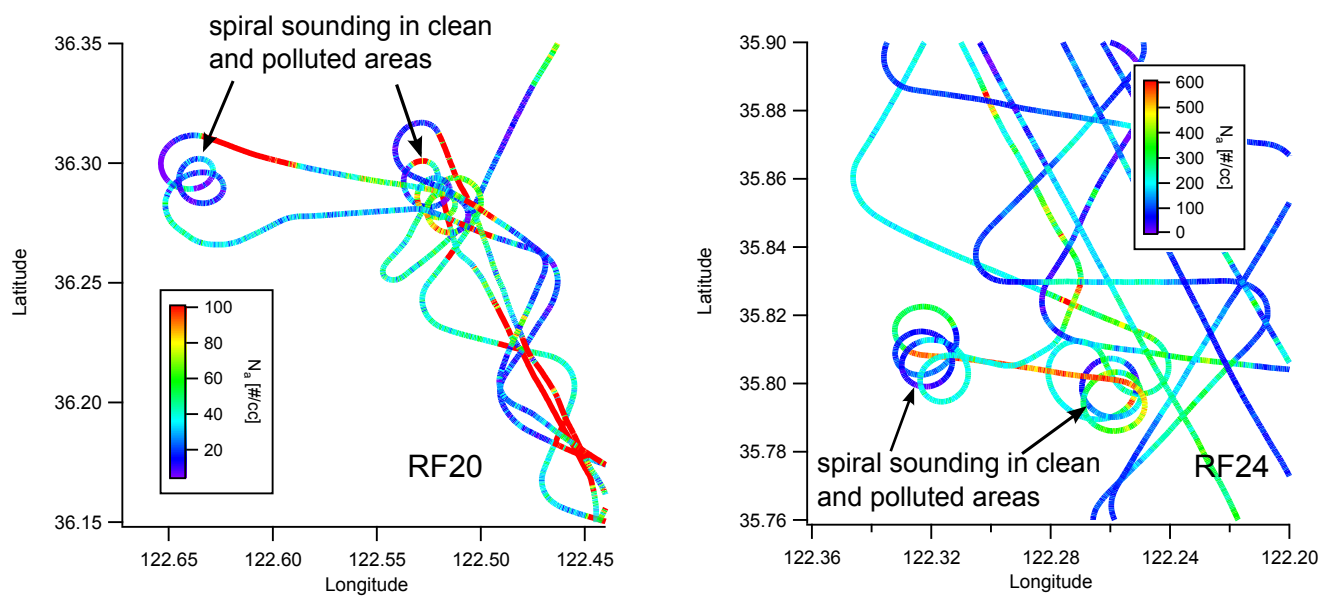

Fig. 1. Spiral soundings of clean and ship exhaust perturbed areas in E-PEACE research flight 20 and 24 (4 and 10 August 2011, respectively). Flight path is colored according to aerosol number concentration (particle diameter $>120 \mathrm{~nm}$ ).

In situ measurements are subject to a variety of uncertainties and limitations. The measurement uncertainty of the probes is documented in several studies (e.g., Baumgardner et al., 2001; Conant et al., 2004; Lance et al., 2010). The probes were repeatedly calibrated during the E-PEACE field mission. The aerosol number concentration $\left(N_{\mathrm{a}}\right)$ was measured by a condensation particle counter (CPC) and a passive cavity aerosol spectrometer probe (PCASP). Cloud droplet size distributions were measured by the cloud, aerosol, and precipitation spectrometer (CAPS), and cloud droplets are defined as those with radius greater than $1.77 \mu \mathrm{m}$ but smaller than drizzle droplets. Drizzle drop size distribution was measured using the Cloud-Imaging Probe (CIP, included in the CAPS package, with size range from $15 \mu \mathrm{m}$ to $1.6 \mathrm{~mm}$ ), and drizzle drops are defined as those with radius greater than $\sim 20 \mu \mathrm{m}$. These values (radius 1.77 and $20 \mu \mathrm{m}$ ) were chosen based on the particle size range of each measuring bin. Cloud droplet is defined as drops with radius larger than $\sim 2 \mu \mathrm{m}$ (e.g., Chen et al., 2011), and the corresponding size bin in CAPS is between 1.77 and $2.35 \mu \mathrm{m}$ in radius. Therefore $1.77 \mu \mathrm{m}$ was chosen as the threshold of cloud droplet size. For drizzle drops, the cutoff radius between cloud and drizzle drops is defined as $25 \mu \mathrm{m}$ (e.g., Wang and Feingold, 2009). The closest size bin in CIP is that ranging from $\sim 20$ to $32 \mu \mathrm{m}$, with $25 \mu \mathrm{m}$ being the geometric mean. Thus $20 \mu \mathrm{m}$ was chosen as the lowest boundary of drizzle drops. The cloud base and top are defined with cloud droplet number concentration $\left(N_{\mathrm{d}}\right)$ threshold $>10 \mathrm{~cm}^{-3}$ and liquid water content (LWC) $>0.01 \mathrm{~g} \mathrm{~m}^{-3}$. LWC is calculated by $\mathrm{LWC}=\int \frac{4}{3} \pi \rho_{\mathrm{W}} r^{3} n(r) \mathrm{d} r$, where $\rho_{\mathrm{W}}$ is density of water, $r$ is droplet radius, and $n(r)$ is the droplet number concentration distribution. Based on the entire cloud layer profile sampled in these four flights, LWP can be estimated using LWP = $\sum(z(i+1)-z(i)) \times\left(\frac{\operatorname{LWC}(i+1)+\operatorname{LWC}(i)}{2}\right)$, where $z(i)$ is the altitude from cloud base $(i=1)$ to cloud top. The cloud droplet effective radius $\left(r_{\mathrm{e}}\right)$ is calculated using $r_{\mathrm{e}}=$ $\int r^{3} n(r) \mathrm{d} r / \int r^{2} n(r) \mathrm{d} r$.

With the drizzle drop size distribution, the rain rate $\left(\mathrm{mmday}^{-1}\right)$ is calculated by Zhao et al. (2011): $R=24 \times$ $0.6 \pi \times 10^{-3} \int_{D_{\min }}^{D_{\max }} D^{3} v(D) n(D) \mathrm{d} D$, where $D$ is the raindrop diameter, and $v(D)$ is the droplet terminal velocity $\left(\mathrm{m} \mathrm{s}^{-1}\right)$, determined by $v(D)=3.778 \times D^{0.67}$ (Zhang et al., 2001). The cloud base rain rate is averaged over the lower quarter of the cloud depth.

Using the cloud droplet spectrum, the cloud optical depth, $\tau$, is calculated by

$\tau=\iint 2 \pi r^{2} n(r) \mathrm{d} r \mathrm{~d} z$,

where the extinction efficiency at visible wavelength is approximately 2 in the geometric optics limit for typical cloud droplet sizes (Seinfeld and Pandis, 2006).

Under adiabatic conditions, a relationship between cloud optical depth and cloud droplet number concentration, $N_{\mathrm{d}}$, can be expressed as (Brenguier et al., 2000):

$\tau=\frac{9}{10}\left(\frac{4}{3} \pi\right)^{\frac{1}{3}} l_{0}^{\frac{2}{3}}\left(k N_{\mathrm{d}}\right)^{\frac{1}{3}} H^{\frac{5}{3}}$,

where $l_{0}=C_{\mathrm{w}} / \rho_{\mathrm{w}}, C_{\mathrm{w}}$ is the moist adiabatic condensation coefficient, ranging from 1 to $2.5 \times 10^{-3} \mathrm{~g} \mathrm{~m}^{-4}$ for temperatures between $0{ }^{\circ} \mathrm{C}$ and $40^{\circ} \mathrm{C}$ (Brenguier et al., 2000); $k$ is a parameter inversely proportional to the droplet distribution breadth (unitless), approaching 0 for a very wide droplet spectrum and 1 for a monodisperse droplet population; and $H$ is cloud thickness. The assumption of adiabatic conditions in Eq. (2) may not be appropriate for heavy drizzling clouds and/or partly cloudy (i.e., open cell cloud) conditions (e.g., 
Hayes et al., 2010). Comparison of cloud albedo susceptibility using Eqs. (1) and (2) will be investigated to evaluate the effect of the adiabatic assumption (Sect. 3.1). From the approximate expression for cloud albedo (Lacis and Hansen, 1974), $A=\tau /(\tau+7.7)$, one obtains $\mathrm{d} A / \mathrm{d} \tau=A(1-A) / \tau$. Together with Eq. (2), the susceptibility of cloud albedo to a perturbation in cloud droplet number concentration can be approximated as:

$$
\frac{\mathrm{d} A}{\mathrm{~d} N_{\mathrm{d}}}=\frac{A(1-A)}{3 N_{\mathrm{d}}}\left(1+\frac{\mathrm{d} \ln k}{\mathrm{~d} \ln N_{\mathrm{d}}}+5 \frac{\mathrm{d} \ln H}{\mathrm{~d} \ln N_{\mathrm{d}}}\right) .
$$

The first term on the R.H.S. of Eq. (3) represents the socalled Twomey effect, the second term is the dispersion effect (i.e., effect of changes in $N_{\mathrm{d}}$ on the cloud droplet size distribution), and the third term expresses the sensitivity of cloud thickness to aerosol perturbations. The cloud thickness response, which can be either positive or negative, is determined by the balance between (a) the moistening/cooling of the marine boundary layer resulting from precipitation suppression, and (b) drying/warming resulting from enhanced entrainment due to increased turbulence (Ackerman et al., 2004; Wood, 2007). Precipitation suppression does not always lead to moistening of the MSc; under certain conditions, it can enhance entrainment and lead to cloud thinning. The three effects represented in Eq. (3) are the major ones governing the response of cloud albedo to a perturbation in cloud droplet number concentration. As an increase in emitted aerosol particles can lead to an increase in $N_{\mathrm{d}}$ (the strength of which depends on background aerosol number concentration, particles acting as cloud condensation nuclei, etc.), Eq. (3) can be applied to the ship exhaust observations, expressing the change between the unperturbed clouds, subject only to the marine background aerosol number concentration (thus background $N_{\mathrm{d}}$ ), and those perturbed by ship exhaust.

For the dispersion effect, the coefficient $k$ is calculated following $\mathrm{Lu}$ and Seinfeld (2006) as a function of relative dispersion $(d)$ and skewness $(s)$ of the droplet number concentration distribution $n(r), k=\frac{\left(1+d^{2}\right)^{3}}{\left(s d^{3}+1+3 d^{2}\right)^{2}}$, where $d=\sigma / \bar{r}$, $\bar{r}$ is mean droplet radius, $\sigma$ is the standard deviation of the droplet spectrum, given by $\sigma=\left(\frac{1}{N_{\mathrm{d}}} \int(r-\bar{r})^{2} n(r) \mathrm{d} r\right)^{1 / 2}$, and skewness $s$ is defined as $s=\frac{1}{\sigma^{3} N_{\mathrm{d}}} \int(r-\bar{r})^{2} n(r) \mathrm{d} r$.

\subsection{Satellite: A-Train data}

The A-Train satellite observations stemmed from the framework of Christensen and Stephens (2012). Using 1-km MODIS imagery over regions on the globe where MSc are prevalent (e.g., the North Pacific Ocean, and adjacent to the coasts of South America and South Africa), ship tracks during the period June 2006-December 2009 were meticulously logged by hand. Polluted and nearby unpolluted clouds identified from MODIS images were co-located to the closest observation from the Cloud-Aerosol Lidar with Orthogonal Polarization (CALIOP) and cloud profiling radar (CPR) on CloudSat. Droplet effective radius and cloud optical thickness were derived from the 3.7- $\mu \mathrm{m}$ reflectances and obtained using the MODIS cloud product (MYD06, King et al., 1998). One-kilometer pixels were screened to include only those with full cloud coverage and fitting the requirement of a single layer, low-level (cloud top pressure greater than $600 \mathrm{hPa}$ ), and warm phase cloud. The screening criteria are similar to those applied in Christensen and Stephens (2012). Cloud albedo was calculated using BUGSrad (Stephens et al., 2001), a two-stream radiative transfer model. LWP was derived from the effective radius and optical depth through LWP $=(2 / 3) \rho_{\mathrm{w}} r_{\mathrm{e}} \tau$ (Stephens, 1978), assuming that the cloud contains spherical droplets and that liquid water content follows an adiabatic vertical profile. These assumptions lead to $\sim 30 \%$ error at the pixel scale, as derived from Bennartz (2007). Therefore, numerous pixels, a minimum of 30 for a ship track, were grouped together into segments to reduce the uncertainty, thereby producing a more representative average of the cloud optical properties derived from MODIS.

In total, 589 ship tracks were identified. Clouds were classified subjectively as closed cell, open cell, unclassifiable, or others (rolled, wavy, streets, etc.) by visually inspecting the region of clouds in a MODIS image $(0.64-\mu \mathrm{m}$ channel) surrounding the ship track. An automated pixel identification scheme, outlined in Christensen and Stephens (2012), was applied to each ship track domain in order to isolate the $1-\mathrm{km}$ MODIS pixels in the ship track from the surrounding unpolluted clouds. Segments, 30-km in length, containing a number of pixels were used to construct reasonably representative averages of the cloud optical properties derived from MODIS for the polluted and unpolluted portions of ship track domains.

\section{Results}

\subsection{Cloud response in ship tracks: in situ observations}

During four of the research flights (RF18, 19, 20, and 24) with spiral soundings and/or slanted ascents, the responses of cloud properties with respect to ship-emitted particles were probed. In each case, the clouds showed marked differences in the microphysical (e.g., effective radius) and macrophysical properties between the unperturbed clouds (in the absence of ship emissions) and those impacted by ship emission plumes. The perturbed clouds exhibited higher cloud droplet number concentration and smaller $r_{\mathrm{e}}$ (Table 2 and Fig. 2), consistent with findings in past field studies of ship tracks (e.g., Radke et al., 1989; Hudson and Yum, 1997; Durkee et al., 2000; Brenguier et al., 2000; Twohy et al., 2005; Lu et al., 2007). 
Table 2. Aerosol/cloud properties measured during E-PEACE Research Flights 18, 19, 20, and 24. For the cloud structure, closed/open means closed or open cloud cellular structure. Cloud layer is defined with cloud droplet number concentration $>10 \mathrm{~cm}^{-3}$ and liquid water content $>0.01 \mathrm{~g} \mathrm{~m}^{-3}$. Mean $N_{\mathrm{a}}, N_{\mathrm{d}}, r_{\mathrm{e}}$ (cloud drop effective radius), and $k$ (droplet spectral shape parameter) are geometric mean values. $\mathrm{BL}$ average $w^{\prime} w^{\prime}$ is the mean vertical velocity variance in the boundary layer. Standard deviation is in parenthesis.

\begin{tabular}{|c|c|c|c|c|c|c|c|c|c|c|c|}
\hline $\begin{array}{l}\text { Research } \\
\text { Flight } \\
(2011)\end{array}$ & & $\begin{array}{l}\text { Cloud } \\
\text { Structure }\end{array}$ & $\begin{array}{l}\text { Cloud } \\
\text { top } \\
(\mathrm{m})\end{array}$ & $\begin{array}{c}\text { Cloud } \\
\text { base } \\
(\mathrm{m})\end{array}$ & $\begin{array}{l}\text { Cloud } \\
\text { thickness } \\
(\mathrm{m})\end{array}$ & $\begin{array}{r}\text { Mean } N_{\mathrm{a}} \\
(>120 \mathrm{~nm})\end{array}$ & $\begin{array}{r}\text { Mean } N_{\mathrm{d}} \\
\left(\mathrm{cm}^{-3}\right)\end{array}$ & $\begin{array}{r}\text { Mean } r_{\mathrm{e}} \\
(\mu \mathrm{m})\end{array}$ & $\begin{array}{r}\text { Cloud base } \\
\text { rain rate } \\
\left(\mathrm{mm} \mathrm{d}^{-1}\right)\end{array}$ & $\begin{array}{c}\text { BL mean } \\
w^{\prime} w^{\prime} \\
\left(\mathrm{m}^{2} \mathrm{~s}^{-2}\right)\end{array}$ & $k$ \\
\hline $\begin{array}{l}\text { RF18 } \\
\text { (2 Aug) }\end{array}$ & Ship & Closed & 598.8 & 475.3 & 123.5 & $379.5(137.7)$ & $316.8(117.4)$ & $5.45(0.84)$ & $\mathrm{n} / \mathrm{a}$ & 0.216 & 0.71 \\
\hline \multirow{2}{*}{$\begin{array}{l}\text { RF19 } \\
\text { (3 Aug) }\end{array}$} & Clean & \multirow[t]{2}{*}{ Closed } & 630.7 & 329.1 & 301.6 & $126.2(82.4)$ & $161.4(33.6)$ & $8.80(1.04)$ & $0.63(0.28)$ & 0.239 & 0.74 \\
\hline & Ship & & 648.2 & 266.2 & 382.0 & $217.6(111.3)$ & 341.7 (127.7) & $7.32(1.18)$ & $0.60(0.32)$ & 0.311 & 0.73 \\
\hline $\begin{array}{l}\text { RF20 } \\
\text { (4 Aug) }\end{array}$ & Ship & Open & 608.6 & 264.8 & 343.8 & $73.4(43.1)$ & $39.0(9.3)$ & $16.01(2.73)$ & $11.40(3.60)$ & 0.113 & 0.57 \\
\hline \multirow{2}{*}{$\begin{array}{l}\text { RF24 } \\
\text { (10 Aug) }\end{array}$} & Clean & \multirow[t]{2}{*}{ Closed } & 607.7 & 238.6 & 369.1 & $115.2(78.2)$ & $153.5(38.7)$ & $9.27(1.57)$ & $1.58(0.54)$ & 0.135 & 0.65 \\
\hline & Ship & & 591.5 & 254.4 & 337.1 & $197.2(96.0)$ & $193.5(80.5)$ & $8.76(1.36)$ & $1.07(0.59)$ & 0.200 & 0.63 \\
\hline
\end{tabular}
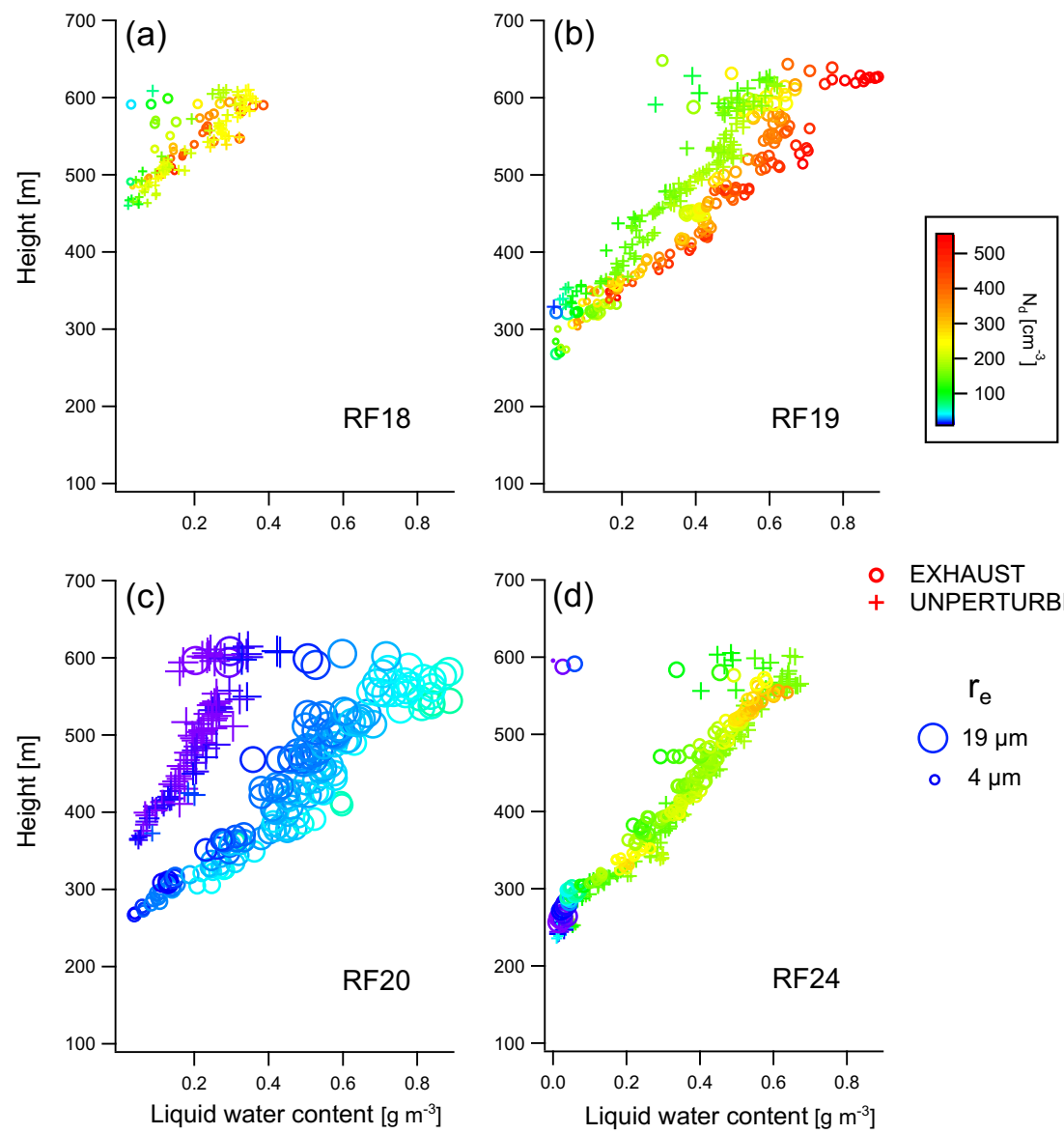

Fig. 2. Cloud microphysical parameters measured along the flight tracks. Each symbol represents data over a $1 \mathrm{~s}$ increment. Cloud droplet number concentration $\left[\mathrm{cm}^{-3}\right]$ is colored on a logarithmic scale; droplet effective radius $\left(r_{\mathrm{e}}\right)$ is given by the size of symbols varying between $\sim 4$ and $19 \mu \mathrm{m}$. Clean and perturbed cloud data are presented by crosses and open circles, respectively. 

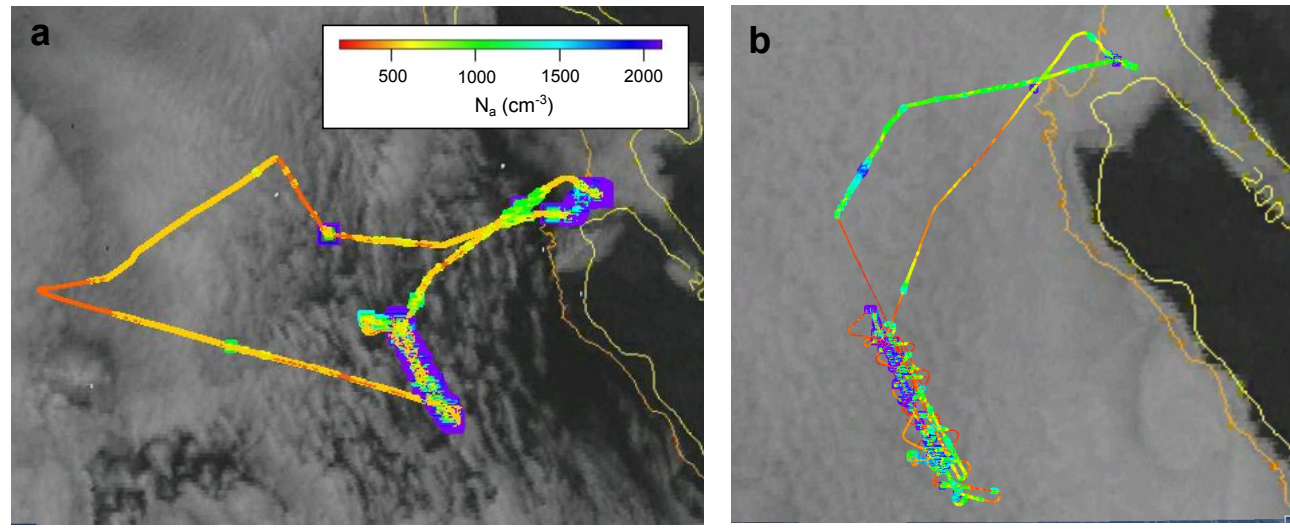

Fig. 3. GOES satellite images. Satellite images during (a) RF20 (4 August 2011) and (b) RF24 (10 August 2011) off coast of Monterey, CA, exemplifying open and closed cell cloud structures, respectively. Flight path is colored according to aerosol number concentration (particle diameter $>10 \mathrm{~nm}$ ).

Table 3. Cloud LWP, optical properties, and environmental conditions measured during E-PEACE Research Flights 18, 19, 20 , and 24. Standard deviation is in parenthesis.

\begin{tabular}{llcccccc}
\hline $\begin{array}{l}\text { Research } \\
\text { Flight }\end{array}$ & & $\begin{array}{c}\text { LWP } \\
\left(\mathrm{g} \mathrm{m}^{-2}\right)\end{array}$ & $\begin{array}{c}\text { Optical } \\
\text { depth } \tau^{\mathrm{a}}\end{array}$ & $\begin{array}{c}\text { Cloud } \\
\text { albedo } A\end{array}$ & $\Delta$ LWP/LWP $^{\mathrm{b}}$ & $\Delta A / A$ & $\begin{array}{c}\text { Dewpoint } \\
\text { depression }^{\mathrm{c}}(\mathrm{K})\end{array}$ \\
\hline RF18 & Clean & 31.0 & 7.3 & 0.49 & -0.33 & -0.12 & $40.0(1.4)$ \\
$(2$ Aug) & Ship & 21.1 & 5.8 & 0.43 & & & \\
\hline RF19 & Clean & 104.0 & 18.4 & 0.70 & 0.62 & 0.16 & $14.3(1.4)$ \\
$(3$ Aug) & Ship & 168.2 & 35.4 & 0.82 & & & \\
\hline RF20 & Clean & 41.5 & 4.6 & 0.37 & & & \\
(4 Aug) & Ship & 158.5 & 16.4 & 0.68 & & & \\
\hline RF24 & Clean & 128.6 & 21.8 & 0.74 & -0.17 & -0.02 & $16.9(1.8)$ \\
$(10$ Aug) & Ship & 107.2 & 20.1 & 0.72 & & & \\
\hline
\end{tabular}

${ }^{a}$ Calculated using Eq. (1).

$\mathrm{b}$ Relative LWP difference between exhaust-perturbed and unperturbed clouds.

c The free tropospheric dewpoint depression $\left(T-T_{\mathrm{d}}\right)$ is averaged over the region from $100 \mathrm{~m}$ above the cloud top to the highest point reached in the flight (on average 100 to $\sim 140 \mathrm{~m}$ above cloud top).

During RF20 (4 August 2011), the clouds were heavily drizzling (Table 2). The presence of heavy drizzle produced an open-cell-like cloud structure (i.e., open spaces ringed by cloud edges, Fig. 3a). Previous studies (Stevens et al., 2005; vanZanten et al., 2005; Savic-Jovcic and Stevens, 2008; Wang and Feingold, 2009) have shown that appreciable precipitation can lead to patchy, scattered cloud, associated with open cellular structures. In the presence of heavy drizzle and solar heating, drizzle evaporation below cloud base and solar absorption tend to promote a stable density stratification within the marine boundary layer (e.g., Stevens et al., 1998; Lewellen and Lewellen, 2002). In the cloud region impacted by the injection of ship exhaust, substantial increases in cloud thickness $($ Clean $=252 \mathrm{~m}$, Ship $=344 \mathrm{~m})$ and LWP $\left(\right.$ Clean $=41.5 \mathrm{~g} \mathrm{~m}^{-2}$, Ship $\left.=158.5 \mathrm{~g} \mathrm{~m}^{-2}\right)$ were ob- served, and the cloud albedo is estimated to have increased by $82 \%$ (using Eq. (1); Table 3). For this optically thin cloud with an open cell structure and low background aerosol number concentration, the injection of ship exhaust produced a much brighter cloud than those neighboring owing to more numerous smaller droplets and higher LWP. Also, numerous smaller droplets in ship tracks is predicted to lead to less efficient coalescence and a slightly lower cloud base precipitation rate, following Albrecht (1989). Such a response has been observed in previous field studies (e.g., Ferek et al., 1998; Lu et al., 2007).

During RF18, 19, and 24, an overcast sky existed with closed cell cloud structures (Fig. 3b). The clouds were nondrizzling in RF18, and lightly drizzling in RF19 and 24. A reduced cloud base rain rate was also evident in RF19 
and RF24 ship exhaust-perturbed conditions. As the perturbed cloud droplet size near cloud top becomes smaller (Fig. 2), reduced sedimentation of cloud droplets near the cloud top entrainment zone tends to cause more efficient cloud top evaporation, enhancing turbulent kinetic energy and entrainment, and leading to smaller LWP and a thinner cloud (Bretherton et al., 2007). These phenomena (less precipitation, higher vertical velocity variance, lower LWP and thinner cloud) are evident in RF18 and RF24 (Table 2).

Among the three closed cell cases, the perturbed cloud in RF19 had higher LWP, cloud thickness, and optical depth than the adjacent clean cloud, similar to that observed in the open cell cloud in RF20. However, the opposite response was observed in RF18 and 24, where decreases in LWP, cloud thickness, and optical depth in the ship track region were found. The difference in cloud macrophysical responses among these cases can be attributed to the ambient thermodynamic conditions. The dewpoint depression (i.e., difference between temperature and dewpoint temperature, an estimate of moisture) above cloud top was much larger in RF18 and 24 as compared to RF19 and 20, indicating a drier free troposphere in these two cases (Table 3). The temperature and humidity variations near cloud top reflect the processes of cloud top entrainment warming and drying (positive $\mathrm{d} \theta / \mathrm{d} z$ and negative $\mathrm{d} q / \mathrm{d} z$ near cloud top; not shown). As the boundary layer dried, the cloud became thinner, with higher cloud base and lower cloud top. Entrainment drying dominated the response of cloud water (Ackerman et al., 2004). In RF18 and RF24, with drier air above the cloud deck in the closed cell cloud structure, not only did the LWP decrease, but the cloud optical depth also decreased by $20.7 \%$ and $7.8 \%$, respectively.

The susceptibility of cloud albedo to increased $N_{\mathrm{d}}$ (i.e., $\mathrm{d} A / \mathrm{d} N_{\mathrm{d}}$ ) was calculated for these four cases to evaluate the change between the unperturbed clouds and those perturbed by ship emission (Fig. 4). Comparing the cloud albedo susceptibility estimated from the analytical formulation based on the adiabatic assumption (Eq. 3) and derived using the droplet size spectrum (using Eq. 1 and $A=\tau /(\tau+7.7)$; see also Table 3), the two derived albedo susceptibilities exhibit only small difference for non-precipitating and lightdrizzling clouds (RF18, 19, and 24, as shown in Fig. 4). However, for heavy drizzling clouds with open cell structure (RF20), the cloud albedo susceptibility derived using Eq. (1) is about twice as large as that from Eq. (3), indicating that the assumption of adiabatic conditions is not applicable for heavy drizzling clouds (see also Hayes et al., 2010). In RF18 and RF24, where negative albedo response (i.e., lower albedo with increased $N_{\mathrm{d}}$ ) was observed, the sign of the cloud thickness effect is negative (Fig. 4), as stronger entrainment drying/warming led to a thinner cloud. The sign of the dispersion effect is also slightly negative in these two cases where non/light drizzle exists. The broadening of the spectrum is caused by the competition for water vapor in the relatively polluted, condensation-dominated regime, offset-

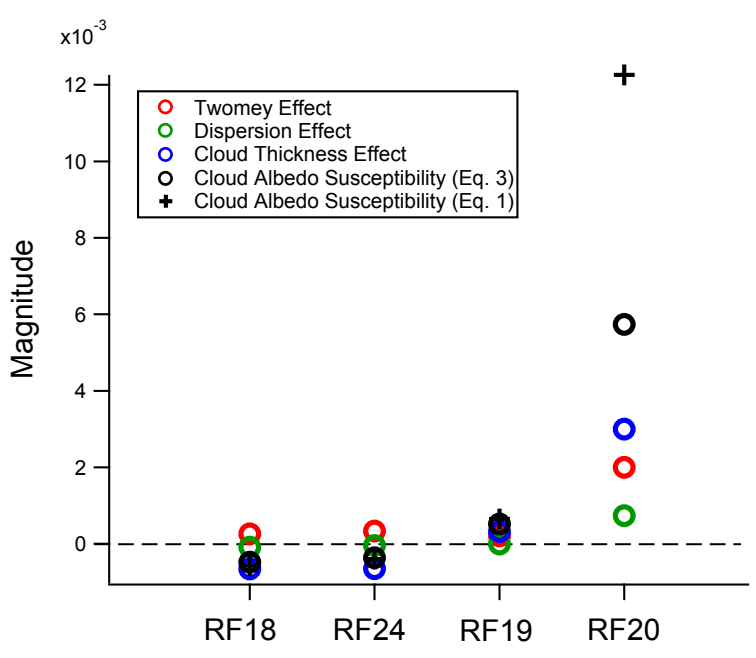

Fig. 4. Magnitude of cloud susceptibility in four E-PEACE cases. Twomey effect (red circle), dispersion effect (green circle), cloud thickness effect (blue circle), and total cloud albedo susceptibility based on Eq. (3) (black circle) and Eq. (1) (black cross) for RF18, RF24, RF19, and RF20 (order from low to high cloud albedo susceptibility).

ting the cooling from the Twomey effect (Feingold and Seibert, 2009). This result is consistent with previous observational studies (e.g., Ackerman et al., 2000; Liu and Daum, 2002). In RF18 and RF24, though the sign of the Twomey effect is positive, it is offset by the negative cloud thickness effect, as the cloud optical depth is five times more sensitive to changes in cloud thickness (Eq. 3). Combined, these effects produced $11.8 \%$ and $2.2 \%$ (for RF18 and RF24, respectively) decreases in cloud albedo in the ship track region.

In RF20, with an open cell cloud structure and an optically thin cloud, the cloud albedo susceptibility is the largest among the four cases. The Twomey effect, dispersion effect, and cloud thickness effect are all positive, with the largest contribution coming from the cloud thickness effect (Fig. 4). The positive dispersion effect (narrower droplet size spectrum under polluted condition) in this heavy-drizzling case is in opposite trend to the cases with non/light drizzle (RF18, 19, 24). This result agrees with the large eddy simulation (LES) studies in Lu and Seinfeld (2006) and Chen et al. (2011), where a larger value of the dispersion effect occurs for clouds with stronger precipitation. With increased aerosol, smaller droplets suppress collisioncoalescence, leading to less spectral broadening. Also, higher updraft velocity (due to stronger turbulence) leads to droplet condensational growth and thus spectral narrowing ( $\mathrm{Lu}$ and Seinfeld, 2006). In RF20, the dispersion effect acts to enhance the Twomey effect. Among these three major effects, the dispersion effect plays a minor role in the total albedo susceptibility. In RF19, with a closed cell cloud structure, cloud susceptibility is also positive. In these two cases (RF19 

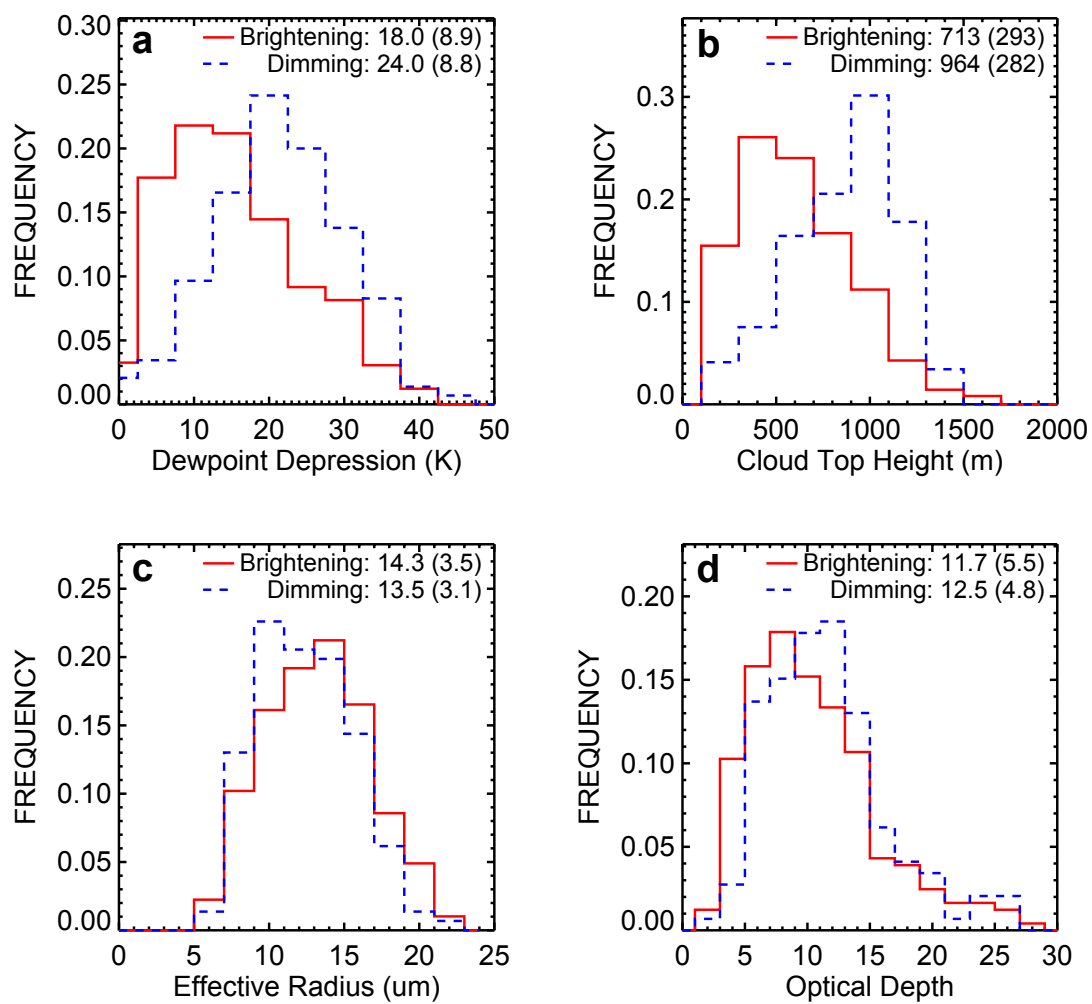

Fig. 5. Frequency distribution of different parameters for 589 individual ship tracks from June 2006-December 2009 A-Train observations. The parameters include: (a) dew point depression, (b) cloud top height, (c) effective radius, and (d) optical depth. Albedo enhancement (brightening) and decrease (dimming) cases are shown by red and blue lines, respectively. Means and (standard deviations) are given at the top of each panel. The cloud top height, effective radius, and optical depth are averaged over the unpolluted cloudy sections of each ship track.

and RF20), the relatively moist overlying air led to less efficient entrainment drying, together with reduction in drizzle, resulting in higher LWP and albedo (cloud brightening).

\subsection{Cloud response in ship tracks: A-Train observations}

Based on 1-km MODIS imagery during the period June 2006-December 2009, 589 ship tracks were classified as closed cell, open cell, unclassifiable, or others by visually inspecting the cloud regions surrounding each ship track using MODIS images.

Among the 589 ship tracks identified, ship plumes enhanced the cloud albedo $\sim 75 \%$ of the time, while $\sim 25 \%$ of the time, a decrease in cloud albedo was observed. Ship tracks were separated into two categories: those with enhanced albedo (cloud brightening) and those with diminished albedo (cloud dimming) as compared to the surrounding clouds (Fig. 5). The average dewpoint depression (average moisture profile above the boundary layer from ECMWFAUX reanalysis data, e.g., Partain, 2004; Benedetti, 2005) is higher in cloud dimming cases $(24.0 \mathrm{~K})$ than those in cloud brightening cases $(18.0 \mathrm{~K})$, consistent with the findings from the in-situ E-PEACE data. Also, the average cloud top height is higher in cases of reduced albedo, as a higher cloud top suggests a greater chance for the cloud layer to be decoupled from the surface moisture supply. This result is similar to that of Wood (2007), in which increasing droplet number concentration leads to cloud thinning in clouds with higher cloud base height (particularly those higher than $400 \mathrm{~m}$ ). Higher clouds, which are relatively decoupled and consequently not as susceptible to aerosol perturbations, were found to exhibit more frequent reduced cloud albedo than lower clouds. A dependence of albedo response on cloud top height was not observed during the E-PEACE flights as the cloud top heights were all below $650 \mathrm{~m}$. Based on the satellite data, the impacts of effective radius and optical depth on albedo response are less evident (Fig. 5). Generally, the average effective radius is slightly smaller, and the average optical depth is slightly larger in ship tracks for which a dimming response was observed than those with brightening response. Despite the higher cloud tops in the cloud dimming regime, smaller droplets in the ambient clouds were observed, suggesting that 


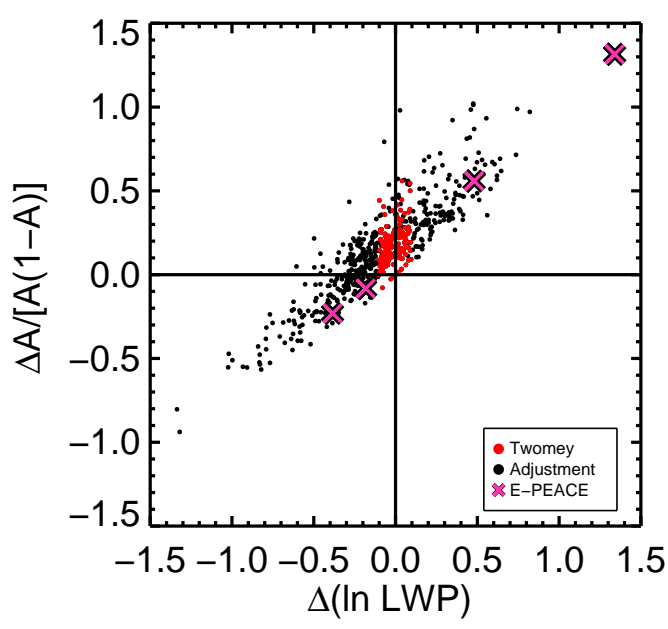

Fig. 6. Fractional change in cloud albedo (Eq. 4) versus the fractional change in logarithm LWP. Indicated are the regime of the Twomey effect (red dots, defined by the absolute value of the fractional change in LWP less than $5 \%$ ) and of LWP feedback adjustment (black dots, in which clouds interacted with the environment, resulting in change in LWP). The four E-PEACE data points (pink) are shown.

droplet growth was suppressed in an environment of drier air above cloud tops. In Christensen and Stephens (2012), the optically thin clouds with larger droplets were the most susceptible to a cloud albedo increase.

The relative change of cloud thickness (or LWP) versus the Twomey effect determines, in short, the cloud albedo response. The dispersion effect is of secondary significance (Fig. 4; also in Chen et al., 2011). Based on Eq. (3), assuming the cloud thickness effect remains constant under quasi-instantaneous changes (i.e., the timescale over which the cloud microphysics adjusts to changes in aerosol concentration is rapid (order of minutes) compared to the macrophysical adjustment timescale), the cloud susceptibility is simply the Twomey effect, and can be expressed as:

$\frac{\Delta A}{A(1-A)}=\frac{1}{3} \Delta\left(\ln N_{\mathrm{d}}\right)$.

When the perturbed and unperturbed clouds are macrophysically similar (i.e., red dots in Fig. 6, defined by the absolute value of the fractional change in LWP and cloud top height less than $5 \%$ ), the regime is defined as the Twomey regime ( $\sim 30 \%$ of ship tracks). As expected, at nearly constant LWP, cloud albedo is higher in the perturbed clouds compared to the surroundings, primarily resulting from increased $N_{\mathrm{d}}$. When the macrophysical differences between perturbed and unperturbed clouds are larger (black dots in Fig. 6, in which clouds interact with the environment, leading to change in LWP), the differences in LWP govern the magnitude and sign of the cloud albedo response. With increased LWP in the ship track, the cloud albedo is increased beyond that predicted by the Twomey effect and, in some ship tracks, the reduction in LWP was so great that the cloud albedo enhancement was dimished to the point where complete cancellation occurred. The four in situ E-PEACE data points (Fig. 6) lie generally within the range of the satellite data distribution.

As the albedo response of the clouds is, to some extent, linked to the cloud top altitude and the dryness of the air above, the effects of the cloud top height and dew point depression on the fractional change in cloud albedo, $r_{\mathrm{e}}$, LWP, and $H$ are depicted in Fig. 7. The impact of the ship plumes on the change in cloud droplet effective radius is relatively constant with cloud top height. On the other hand, fractional changes in LWP caused by the plume become increasingly negative as the cloud top height increases, in agreement with Christensen and Stephens (2012). Also, as the dew point depression above cloud top increases (drier air), the fractional change in LWP becomes increasingly negative. As the cloud albedo response follows closely the LWP response, the cloud brightening is diminished under drier free troposphere or higher cloud top heights. Cloud top height and dewpoint depression exert strong controls on the LWP response.

Clouds were classified as closed cell, open cell, unclassifiable, or others. In the closed cell regime, nearly $30 \%$ of ship tracks exhibit decreased cloud albedo. In the open cell and unclassifiable regimes, $\sim 14 \%$ and $19 \%$ of the ship tracks, respectively, exhibit decreased albedo.

\section{Conclusions}

The coupling among aerosol, cloud, precipitation, and meteorological conditions in the marine boundary layer is complex (Fig. 8). The so-called Twomey and Albrecht effects can lead to cloud brightening and thus cooling. On the other hand, in response to an aerosol perturbation, reduced incloud sedimentation leads to an increase of cloud water and evaporation in entrainment regions, resulting in stronger entrainment (Ackerman et al., 2004; Bretherton et al., 2007). Besides, less drizzle reduces below-cloud evaporative cooling and in-cloud latent heat release, resulting in higher turbulent kinetic energy and thus stronger entrainment (Wood, 2007). In this study, we evaluate, based on both in-situ and satellite data, the effect of environmental conditions, cloud cellular structures, and cloud properties (e.g., cloud top height, extent of drizzle) on cloud albedo responses to ship emissions. Cloud brightening is evident in an open cellular cloud structure with relatively moist air above cloud top. The opposite effect appears in the presence of a drier free troposphere in a closed cellular cloud structure. With sufficiently dry air above cloud tops, the enhanced entrainment drying/warming facilitated by smaller droplets in polluted clouds leads to lower LWP and thinner clouds. When 

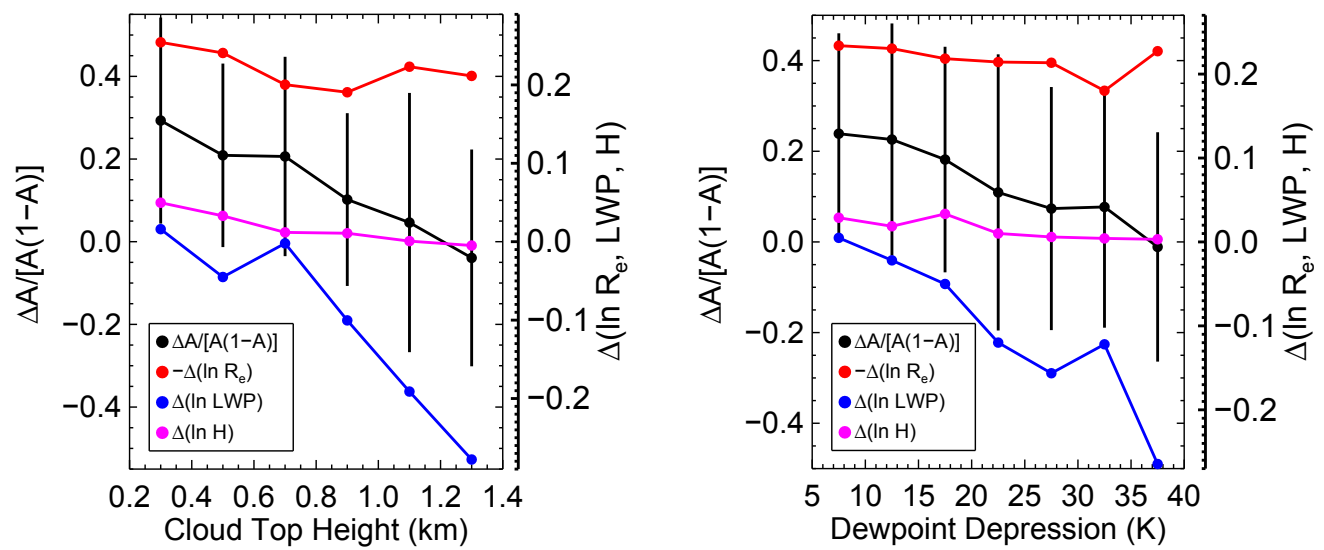

Fig. 7. Binned change in albedo, effective radius $\left(r_{\mathrm{e}}\right)$, LWP, and cloud thickness $(H)$ as a function of cloud top height (left panel), and dew point depression (right panel) based on 589 ship tracks observed over June 2006-December 2009. Cases were binned by $200 \mathrm{~m}$ wide bins in cloud top height and $5 \mathrm{~K}$ wide bins in dewpoint depression. A minimum of 20 ship tracks was required for each bin. Error bars were determined from the standard deviation of average cloud albedos taken from the population of ship tracks in each bin. The length of the error bars extends over two standard deviations; i.e., the bar extends one standard deviation below and one above the mean for each bin.

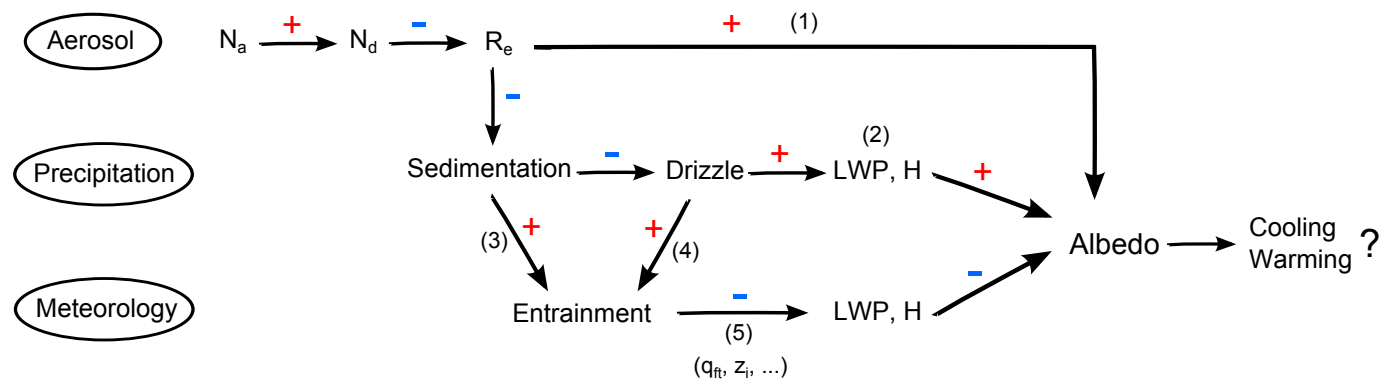

Fig. 8. Conceptual diagram displaying the interactions among aerosol, cloud, precipitation, and meteorology. The response of each property/phenomenon to increased aerosol $\left(N_{\mathrm{a}}\right)$ is shown as a red plus (signifying positive response), and a blue minus (negative response) sign. Footnotes to figure: (1) Twomey effect (Twomey, 1991). (2) Albrecht effect (Albrecht, 1989). (3) Sedimentation-entrainment effect (Bretherton et al., 2007). (4) Drizzle-entrainment effect (Wood, 2007). (5) Significant meteorological conditions, such as free tropospheric humidity $\left(q_{\mathrm{ft}}\right)$, large scale divergence rate, as well as cloud top height $\left(z_{i}\right)$, can control the MSc structure (Wood, 2007; Chen et al., 2011).

the negative cloud thickness effect outweighs the positive Twomey effect (Eq. 3), a lower cloud albedo results. Based on over 3 yr of satellite data, both the dryness of the air above the marine boundary layer and cloud top heights are seen to play significant roles in determining the albedo response. In the cases in which cloud albedo actually decreased, cloud top heights were higher and capped by very dry overlying air. In classification of cloud cellular regimes, $30 \%$ of the closed cell ship tracks exhibited lower cloud albedo.

The satellite data show that, on average, $75 \%$ of the ship tracks are brighter than the surrounding clouds. When taken as a whole, the polluted clouds are about $2-3 \%$ more reflective than the surrounding clouds. The ship track radiative forcing at the local scale (averaged over numerous ship tracks) is on the order of $\sim-10$ to $-20 \mathrm{Wm}^{-2}$ (e.g., Coakley et al., 1987; Christensen and Stephens, 2011). On the global scale, however, negligible radiative forcing from ship tracks has been observed (Schreier et al., 2007; Peters et al., 2011). In the current study, $\sim 25 \%$ of the ship tracks produce a positive radiative forcing, the strength of which depends on the depth of the cloud (or decoupling) and the free-troposphere humidity. The current study employs ship track observations as means to assess the microphysics of aerosol-cloud relationships. Further studies are needed to quantify these effects on global scale.

While the present study has been motivated predominantly by gaining a more thorough understanding of the response of marine stratocumulus to perturbations in aerosol concentrations, it has obvious implications in terms of marine cloud brightening geo-engineering. There are some important differences, however; when the boundary layer is wellmixed the buoyancy of ship exhaust may increase the amount 
of ship effluent entering the overlying clouds (Liu et al., 2000), whereas the surface generation of sea-salt particles, as demonstrated in the ship wake observations of Durkee et al. (2000), lead to a plume that is largely neutrally buoyant. The extent to which the added buoyancy from the plume aids in ship track formation is confounded by the observations from Hobbs et al. (2000) which demonstrate that the heat and moisture associated with ship exhaust dissipate rapidly into the boundary layer. Thus, the efficiency of vertical transport of a plume of sea salt aerosol, under a variety of conditions, needs to be considered in the design of a geo-engineering strategy.

Cloud macrophysical responses are crucial in determining both the strength and the sign of the cloud albedo response to aerosols intentionally injected into the marine boundary layer. These responses must be accounted for in global studies of the potential efficacy of sea spray geo-engineering as a means to counteract global warming.

Acknowledgements. This work was supported by Office of Naval Research grants N00014-10-1-0200 and N00014-10-1-0811, and National Science Foundation grant AGS-1008848. Y.-C. C. thanks D. Axisa, H. Jonsson, Z. Wang and H. Duong for help on aircraft data analysis. Y.-C. C. and L. X. also thank the support from the Advanced Study Porgram at NCAR.

Edited by: B. Stevens

\section{References}

Ackerman, A. S., Toon, O. B., Taylor, J. P., Johnson, D. W., Hobbs, P. V., and Ferek, R. J.: Effects of aerosols on cloud albedo: Evaluation of Twomey's parameterization of the cloud susceptibility using measurement of ship tracks, J. Atmos. Sci., 57, 2684-2695, 2000 .

Ackerman, A. S., Kirkpatrick, M. P., Stevens, D. E., and Toon, O. B.: The impact of humidity above stratiform clouds on indirect aerosol climate forcing, Nature, 432, 1014-1017, 2004.

Albrecht, B.: Aerosols, cloud microphysics, and fractional cloudiness, Science, 245, 1227-1230, doi:10.1126/science.245.4923.1227, 1989.

Bala, G., Caldeira, K., Nemani, R., Cao, L., Ban-Weiss, G., and Shin, H.-J.: Albedo enhancement of marine cloud to counteract global warming: impacts on the hydrological cycle, Clim. Dynam., 37, 915-931, doi:10.1007/s00382-010-0868-1, 2011.

Baumgardner, D., Jonsson, H., Dawson, W., O'Connor, D., and Newton, R.: The cloud, aerosol and precipitation spectrometer: a new instrument for cloud investigations, Atmos. Res., 59, 251264, doi:10.1016/S0169-8095(01)00119-3, 2001.

Benedetti, A.: CloudSat AN-ECMWF ancillary data interface control document, Cooperative Institute for Research in the Atmosphere, Colorado State University, Fort Collins, CO 80523, 2005.

Bennartz, R.: Global assessment of marine boundary layer cloud droplet number concentration from satellite, J. Geophys. Res., 112, D02201, doi:10.1029/2006JD007547, 2007.

Bower, K., Choularton, T., Latham, J., Sahraei, J., and Salter, S.: Computational assessment of a proposed technique for global warming mitigation via albedo-enhancement of marine stratocumulus clouds, Atmos. Res., 82, 328-336, doi:10.1016/j.atmosres.2005.11.013, 2006.

Brenguier, J.-L., Pawloska, H., Schüller, L., Preusker, R., and Fischer, J.: Radiative properties of boundary layer clouds: Droplet effective radius versus number concentration, J. Atmos. Sci., 57, 803-821, 2000.

Bretherton, C. S., Blossey, P. N., and Uchida, J.: Cloud droplet sedimentation, entrainment efficiency, and subtropical stratocumulus albedo, Geophys. Res. Lett., 34, L03813, doi:10.1029/2006GL027648, 2007.

Chen, Y.-C., Xue, L., Lebo, Z. J., Wang, H., Rasmussen, R. M., and Seinfeld, J. H.: A comprehensive numerical study of aerosolcloud-precipitation interactions in marine stratocumulus, Atmos. Chem. Phys., 11, 9749-9769, doi:10.5194/acp-11-9749-2011, 2011.

Christensen, M. W. and Stephens, G. L.: Microphysical and macrophysical responses of marine stratocumulus polluted by underlying ships: Evidence of cloud deepening, J. Geophys. Res., 116, D03201, doi:10.1029/2010JD014638, 2011.

Christensen, M. W. and Stephens, G. L.: Microphysical and macrophysical responses of marine stratocumulus polluted by underlying ships. Part 2: Impacts of haze on precipitating clouds, J. Geophys. Res., 117, D11203, doi:10.1029/2011JD017125, 2012.

Coakley, J. A. and Walsh, C. D.: Limits to the aerosol indirect radiative effect derived from observations of ship tracks, J. Atmos. Sci., 59, 668-680, doi:10.1175/15200469(2002)059<0668:LTTAIR>2.0.CO;2, 2002.

Coakley, J. A., Bernstein, J. R., and Durkee, P. A.: Effect of ship track effluents on cloud reflectivity, Science, 237, 1020-1021, 1987.

Conant, W. C., VanReken, T. M., Rissman, T. A., Varutbangkul, V., Jonsson, H. H., Nenes, A., Jimenez, J. L., Delia, A. E., Bahreini, R., Roberts, G. C., Flagan, R. C., and Seinfeld, J. H.: Aerosolcloud drop concentration closure in warm cumulus, J. Geophys. Res., 109, D13204, doi:10.1029/2003JD004324, 2004.

Durkee, P. A., Noone, K. J., and Bluth, R. T.: The Monterey area ship track experiment, J. Atmos. Sci., 57, 2523-2541, doi:10.1175/1520-0469(2000)057<2523:TMASTE > 2.0.CO;2, 2000.

Feingold, G. and Seibert, H.: Cloud-Aerosol Interactions from the micro to cloud scale, in: Clouds in the perturbed climate system: their relationship to energy balance, atmospheric dynamics, and precipitation, edited by: Heintzenberg, J. and Charlson, R. J., MIT Press, 2009.

Ferek, R. J., Hegg, D. A., Hobbs, P. V., Durkee, P., and Nielsen, K.: Measurements of ship-induced cloud tracks off the Washington coast, J. Geophys. Res., 103, 23199-23206, doi:10.1029/98JD02121, 1998.

Hayes, C. R., Coakley, J. A., and Tahnk, W. R.: Relationships among properties of marine stratocumulus derived from collocated CALIPSO and MODIS observations, J. Geophys. Res., 115, D00H17, doi:10.1029/2009JD012046, 2010.

Hobbs, P. V., Garrett, T. J., Ferek, R. J., Strader, S. R., Hegg, D. A., Frick, G. M., Hoppel, W. A., Gasparovic, R. F., Russell, L. M., Johnson, D. W., O’Dowd, C., Durkee, P. A., Nielsen, K. E., and Innis, G.: Emissions from ships with respect to their effects on clouds, J. Atmos. Sci., 57, 2570-2590, doi:10.1175/15200469(2000)057<2570:EFSWRT>2.0.CO;2, 2000. 
Hudson, J. G. and Yum, S. S.: Droplet spectral broadening in marine stratus, J. Atmos. Sci., 54, 2642-2654, doi:10.1175/15200469(1997)054<2642:DSBIMS > 2.0.CO;2, 1997.

IPCC: Summary for Policymakers, in: Climate Change 2007: The Physical Science Basis. Contribution of Working Group I to the Fourth Assessment Report of the Intergovernmental Panel on Climate Change, edited by: Solomon, S., Qin, D., Manning, M., Chen, Z., Marquis, M., Averyt, K. B., Tignor, M., and Miller, H. L., Cambridge University Press, 2007.

Jones, A., Haywood, J., and Boucher, O.: Climate impacts of geoengineering marine stratocumulus clouds, J. Geophys. Res., 114, D10106, doi:10.1029/2008JD011450, 2009.

King, M., Tsay, S.-C., Platnick, S., Wang, M., and Liou, K.-N.: Cloud retrieval algorithms for MODIS: Optical thickness, effective particle radius, and thermodynamic phase, Algorithm Theor. Basis Doc. ATBDMOD-05, NASA Goddard Space Flight Cent., 1998.

Korhonen, H., Carslaw, K. S., and Romakkaniemi, S.: Enhancement of marine cloud albedo via controlled sea spray injections: a global model study of the influence of emission rates, microphysics and transport, Atmos. Chem. Phys., 10, 4133-4143, doi:10.5194/acp-10-4133-2010, 2010.

Lacis, A. A. and Hansen, J. E.: A parameterization for the absorption of solar radiation in the Earth's atmosphere, J. Atmos. Sci., 31, 118-133, doi:10.1175/15200469(1974)031<0118:APFTAO>2.0.CO;2, 1974.

Lance, S., Brock, C. A., Rogers, D., and Gordon, J. A.: Water droplet calibration of the Cloud Droplet Probe (CDP) and inflight performance in liquid, ice and mixed-phase clouds during ARCPAC, Atmos. Meas. Tech., 3, 1683-1706, doi:10.5194/amt3-1683-2010, 2010.

Latham, J., Rasch, P., Chen, C.-C., Kettles, L., Gadian, A., Gettelman, A., Morrison, H., Bower, K., and Choularton, T.: Global temperature stabilization via controlled albedo enhancement of low-level maritime clouds, Philos. Trans. Roy. Soc. London, 366, 3969-3987, doi:10.1098/rsta.2008.0137, 2008.

Lebsock, M. D., Stephens, G. L., and Kummerow, C.: Multisensor satellite observations of aerosol effects on warm clouds, J. Geophys. Res., 113, D15205, doi:10.1029/2008JD009876, 2008.

Lewellen, D. C. and Lewellen, W. S.: Entrainment and decoupling relations for cloudy boundary layers, J. Atmos. Sci., 59, 2966-2986, doi:10.1175/15200469(2002)059<2966:EADRFC>2.0.CO;2, 2002.

Liu, Q., Kogan, Y. L., Lilly, D. K., Johnson, D. W., Innis, G. E., Durkee, P. A., and Nielsen, K. E.: Modeling of ship effluent transport and its sensitivity to boundary layer structure, J. Atmos. Sci., 57, 2779-2791, doi:10.1175/15200469(2000)057<2779:MOSETA > 2.0.CO;2, 2000.

Liu, Y. G. and Daum, P. H.: Anthropogenic aerosols: Indirect warming effect from dispersion forcing, Nature, 419, 580-581, 2002.

Lohmann, U. and Feichter, J.: Global indirect aerosol effects: a review, Atmos. Chem. Phys., 5, 715-737, doi:10.5194/acp-5-7152005, 2005.

Lu, M. and Seinfeld, J. H.: Effect of aerosol number concentration on cloud droplet dispersion: A large-eddy simulation study and implications for aerosol indirect forcing, J. Geophys. Res., 111, D02207, doi:10.1029/2005JD006419, 2006.

Lu, M.-L., Conant, W. C., Jonsson, H. H., Varutbangkul, V., Flagan, R. C., and Seinfeld, J. H.: The Marine Stra-
tus/Stratocumulus Experiment (MASE): Aerosol-cloud relationships in marine stratocumulus, J. Geophys. Res., 112, D10209, doi:10.1029/2006JD007985, 2007.

Lu, M.-L., Sorooshian, A., Jonsson, H. H., Feingold, G., Flagan, R. C., and Seinfeld, J. H.: Marine stratocumulus aerosol-cloud relationships in the MASE-II experiment: Precipitation susceptibility in eastern Pacific marine stratocumulus, J. Geophys. Res., 114, D24203, doi:10.1029/2009JD012774, 2009.

Partain, P.: Cloudsat ECMWF-AUX auxiliary data process description and interface control document, Cooperative Institute for Research in the Atmosphere, Colorado State University, Fort Collins, CO 80523, 2004.

Partanen, A.-I., Kokkola, H., Romakkaniemi, S., Kerminen, V.-M., Lehtinen, K. E. J., Bergman, T., Arola, A., and Korhonen, H.: Direct and indirect effects of sea spray geoengineering and the role of injected particle size, J. Geophys. Res., 117, D02203, doi:10.1029/2011JD016428, 2012.

Peters, K., Quaas, J., and Grassl, H.: A search for large-scale effects of ship emissions on clouds and radiation in satellite data, J. Geophys. Res., 116, D24205, doi:10.1029/2011JD016531, 2011.

Pringle, K. J., Carslaw, K. S., Fan, T., Mann, G.W., Hill, A., Stier, P., Zhang, K., and Tost, H.: A multi-model assessment of the efficacy of sea spray geoengineering, Atmos. Chem. Phys. Discuss., 12, 7125-7166, doi:10.5194/acpd-12-7125-2012, 2012.

Radke, L. F., Coakley, J. A., and King, M. D.: Direct and remote sensing observations of the effects of ships on clouds, Science, 246, 1146-1149, doi:10.1126/science.246.4934.1146, 1989.

Rasch, P. J., Latham, J., and Chen, C.-C.: Geoengineering by cloud seeding: influence on sea ice and climate system, Environ. Res. Lett., 4, 1290-1301, doi:10.1088/1748-9326/4/4/045112, 2009.

Russell, L. M., Seinfeld, J. H., Flagan, R. C., Ferek, R. J., Hegg, D. A., Hobbs, P. V., Wobrock, W., Flossmann, A., O’Dowd, C. D., Nielsen, K. E., and Durkee, P. A.: Aerosol dynamics in ship tracks, J. Geophys. Res., 104, 31077-31095, 1999.

Russell, L. M., Sorooshian, A., Seinfeld, J. H., Albrecht, B. A., Nenes, A., Ahlm, L., Chen, Y.-C., Coggon, M., Craven, J. S., Flagan, R. C., Frossard, A. A., Jonsson, H., Jung, E., Lin, J. J., Metcalf, A. R., Modini, R., Muelmenstaedt, J., Roberts, G. C., Shingler, T., Song, S., Wang, Z., and Wonaschuetz, A.: Eastern Pacific Emitted Aerosol Cloud Experiment (E-PEACE), B. Am. Meteorol. Soc., submitted, 2012.

Salter, S., Sortino, G., and Latham, J.: Sea-going hardware for the cloud albedo method of reversing global warming, Philos. Trans. Roy. Soc. London, 366, 3989-4006, doi:10.1098/rsta.2008.0136, 2008.

Savic-Jovcic, V. and Stevens, B.: The structure and mesoscale organization of precipitating stratocumulus, J. Atmos. Sci., 65, 15871605, 2008.

Schreier, M., Mannstein, H., Eyring, V., and Bovensmann, H.: Global ship track distribution and radiative forcing from 1 year of AATSR data, Geophys. Res. Lett., 34, L17814, doi:10.1029/2007GL030664, 2007.

Segrin, M. S., Coakley, J. J. A., and Tahnk, W. R.: MODIS observations of ship tracks in summertime stratus off the west coast of the United States, J. Atmos. Sci., 64, 4330-4345, doi:10.1175/2007JAS2308.1, 2007.

Seinfeld, J. H. and Pandis, S. N.: Atmospheric Chemistry and Physics, John Wiley and Sons, Inc., Hoboken, NJ, 2nd Edn., 2006. 
Stephens, G. L.: Radiation profiles in extended water clouds. Part II: Parameterization schemes, J. Atmos. Sci., 35, 2123-2132, doi:10.1175/1520-0469(1978)035<2123:RPIEWC > 2.0.CO;2, 1978.

Stephens, G. L., Gabriel, P. M., and Partain, P. T.: Parameterization of atmospheric radiative transfer. Part I: Validity of simple models, J. Atmos. Sci., 58, 3391-3409, 2001.

Stevens, B. and Brenguier, J.-L.: Cloud controlling factors: low clouds, in: Clouds in the perturbed climate system: their relationship to energy balance, atmospheric dynamics, and precipitation, edited by: Heintzenberg, J. and Charlson, R. J., MIT Press, 173196, 2009.

Stevens, B. and Feingold, G.: Untangling aerosol effects on clouds and precipitation in a buffered system, Nature, 461, 607-613, doi:10.1038/nature08281, 2009.

Stevens, B., Cotton, W. R., Feingold, G., and Moeng, C.H.: Large-eddy simulations of strongly precipitating, shallow, stratocumulus-topped boundary layers, J. Atmos. Sci., 55, 36163638, 1998.

Stevens, B., Vali, G., Comstock, K., vanZanten, M. C., Austin, P. H., Bretherton, C. S., and Lenschow, D. H.: Pockets of open cells and drizzle in marine stratocumulus, B. Am. Meteorol. Soc., 86, 51-57, 2005.

Twohy, C. H., Petters, M. D., Snider, J. R., Stevens, B., Tahnk, W., Wetzel, M., Russell, L., and Burnet, F.: Evaluation of the aerosol indirect effect in marine stratocumulus clouds: Droplet number, size, liquid water path, and radiative impact, J. Geophys. Res., 110, D08203, doi:10.1029/2004JD005116, 2005.

Twomey, S.: Aerosols, clouds, and radiation, Atmos. Environ., 25, 2435-2442, 1991.
vanZanten, M. C., Stevens, B., Vali, G., and Lenschow, D. H.: Observations of Drizzle in Nocturnal marine stratocumulus, J. Atmos. Sci., 62, 88-106, 2005.

Wang, H. and Feingold, G.: Modeling mesoscale cellular structures and drizzle in marine stratocumulus. Part I: Impact of drizzle on the formation and evolution of open cells, J. Atmos. Sci., 66, 3237-3256, 2009.

Wang, H., Rasch, P. J., and Feingold, G.: Manipulating marine stratocumulus cloud amount and albedo: a process-modelling study of aerosol-cloud-precipitation interactions in response to injection of cloud condensation nuclei, Atmos. Chem. Phys., 11, 4237-4249, doi:10.5194/acp-11-4237-2011, 2011.

Warren, S. G., Hahn, C. J., London, J., Chervine, R. M., and Jenne, R. L.: Global distribution of total cloud cover and cloud type amounts over the ocean, NCAR/TN-317 STR, NCAR Tech. Note., 41 pp., 1988.

Wood, R.: Cancellation of aerosol indirect effects in marine stratocumulus through cloud thinning, J. Atmos. Sci., 64, $2657-$ 2669, doi:10.1175/JAS3942.1, 2007.

Zhang, G., Vivekanandan, J., and Brandes, E.: A method for estimating rain rate and drop size distribution from polarimetric radar measurements, IEEE T. Geosci. Remote, 39, 830-841, 2001.

Zhao, G., Chu, R., Zhang, T., Li, J., Shen, J., and Wu, Z.: Improving the rainfall rate estimation in the midstream of the Heihe River Basin using raindrop size distribution, Hydrol. Earth Syst. Sci., 15, 943-951, doi:10.5194/hess-15-943-2011, 2011. 